\title{
Effect of in ovo folic acid injection on hepatic IGF2 expression and embryo growth of broilers
}

\author{
Yanli Liu', Lihui Zhi ${ }^{2}$ Jing Shen', Shizhao Li ${ }^{1}$, Junhu Yao ${ }^{1}$ and Xiaojun Yang ${ }^{1 *}$
}

\begin{abstract}
Background: Insulin-like factor 2 (IGF2) plays an important role in embryonic growth process by modulating intermediary metabolism and cell proliferation. Folic acid is involved in one carbon metabolism and contributes to DNA methylation which is related to gene expression. The purpose of this study was to explore whether folic acid could regulate IGF2 expression via epigenetic mechanism and further promote embryonic growth of new-hatched broilers.
\end{abstract}

Methods: In the present study, 360 fertile eggs were selected and randomly assigned to four treatments. On 11 embryonic day of incubation (E11), 0, 50, 100 and $150 \mu \mathrm{g}$ folic acid were injected into eggs respectively. After hatched, growth performance of broilers were calculated. Hepatic IGF2 expression, methylation level and chromatin structure of promoter region were analyzed.

Results: Results have showed that IGF2 expression was up-regulated in $150 \mu \mathrm{g}$ folic acid group $(P<0.05)$ and other two dose of folic acid did not affect gene expression ( $P>0.05)$. Meanwhile, methylation level of IGF2 promoter were lower in 100 and $150 \mu \mathrm{g}$ groups, which was consistent with lower expression of DNA methyltransferase 1 (DNMT1) $(P<0.05)$. What's more, chromatin looseness of IGF2 promoter was higher in $150 \mu \mathrm{g}$ group than control group $(P<0.05)$. Further, birth weight $(B W)$, liver and bursa index of new-hatched chickens in $150 \mu \mathrm{g}$ folic acid group were higher than the other groups $(P<0.05)$. There were positive correlations between hepatic IGF2 expression and BW and organs index $(P<0.05)$.

Conclusion: In conclusion, our data have demonstrated that $150 \mu \mathrm{g}$ folic acid injection on E11 could up-regulate IGF2 expression by modulating DNA hypomethylation and improving chromatin accessibility in the gene promoter region, and ulteriorly facilitate embryonic growth and organ development of broilers.

Keywords: Broiler, Chromatin structure, Folic acid, Insulin-like growth factor 2, Methylation

\section{Background}

Insulin-like growth factor 2 (IGF2) has been generally studied in eutherian mammals and marsupial for the reason that IGF2/H19 are imprinted and IGF2 is associated with performance traits. However, genomic imprinting phenomenon has never been detected in chickens and $H 19$ gene is absent from the chicken sequence [1]. IGF2 is located on chromosome 5 and displays a biallelic pattern of expression during chicken development [2].

\footnotetext{
* Correspondence: yangxj@nwsuaf.edu.cn

${ }^{1}$ College of Animal Science and Technology, Northwest A\&F University, Yangling 712100, China

Full list of author information is available at the end of the article
}

Previous detailed reviews have reported the role of IGFs and provided ample evidence suggesting that IGFs were involved in DNA and protein synthesis, glucose and energy metabolism and lipid metabolism in poultry $[3,4]$. Similarly to mammals, as an appropriate selection candidate gene, IGF2 is also associated with economical traits of chicken such as muscle growth, body composition, embryonic growth and differentiation $[2,5]$.

The chicken is an important model organism in oviparous animals, and this species is well characterized in many biological aspects and bridges the evolutionary gap between mammals and other vertebrates [6]. Whereas, the energy and nutrients needed during embryonic development and 
growth of avian are stored in the egg. Nutritionally, the yolk, the egg richest fraction, is the primary source of nutrition. In ovo injection, a unique way of introducing nutrients into the incubating embryo, is used in poultry to improve nutritional level of eggs. Studies have indicated that in ovo injection of amino acids, vitamins as well as trace elements can enhance growth of the embryo and improve immune response during post-hatch development in chickens [7].

Folic acid is a key one carbon group involved in DNA, RNA and protein methylation as well as DNA synthesis and maintenance [8]. Epigenetics is to study the heritable changes in phenotype or gene expression without changes in the primary DNA sequence [9]. Many researches have reported the relationship between folic acid and DNA methylation [8, 10, 11]. IGF2 is mainly synthesized in liver and plays an important role in embryonic development of avian species via autocrine/ paracrine mechanisms [12]. Moreover, transgenic and gene knockout mouse models have demonstrated that $I G F 2$ is required for tissue growth and fetal normal development $[13,14]$.

To sum up, on account of the importance of IGF2 function, it will be valuable to study regulatory mechanism of IGF2 expression, but to date correlational studies whether early nutrient supplementation might affect gene expression via epigenetic ways are scarce in poultry. Considering special characters during chicken growing and development, the present investigation was carried out to explore the effects of in ovo folic acid injection on hepatic IGF2 expression and embryo development of broilers.

\section{Methods}

\section{Animals experiment}

In the study, $360 \mathrm{Cobb}$ fertile eggs whose weight were among $65.7 \pm 0.3 \mathrm{~g}$ were randomly assigned to four treatments (6 replicates/treatment, 15 birds/replicate). The experimental eggs were hatched in the microcomputer automatic incubator (Beijing LanTianJiao Electronic Technology Co., LTD, Beijing, China). All replicates of four treatments were arranged locally equalization as much as possible before hatching. Folic acid (Sigma, USA) was dissolved in sterile saline at 500, 1000 and $1500 \mu \mathrm{g} / \mathrm{mL}$. Folic acid solution $(0.1 \mathrm{~mL})$ was injected into the yolk sac on E11 for three treatments respectively and another treatment was injected $0.1 \mathrm{~mL}$ saline as the control. The detailed injection methods were on the basis of previous report [15]. Injection time for folic acid was chosen according to the preliminary test where we have set set three times (E3, E7 and E11) for injection. Based on preliminary results (data not shown) and previous research [16], we select E11 as injection age in this study.

\section{Sample collection}

During egg incubation, infertile and dead eggs were removed and recorded. After hatched, the fertilized hatchability was calculated by the formula: (the number of hatching birds/the number of fertilized eggs) * $100 \%$. One healthy bird was selected from each replicate to rapidly dissect whose weight was close to average value of the replicate. The liver, spleen, heart and bursa were removed and weighted immediately to calculate organ index. After weighting, all tissues were collected and frozen in liquid nitrogen. All samples were stored at $-80{ }^{\circ} \mathrm{C}$ until analysis. All experimental protocol in the study was approved by the Animal Care and Use Committee of the College of Animal Science and Technology of the Northwest A\&F University (Shaanxi, China).

\section{Genomic DNA and total RNA preparation}

TIANamp Genomic DNA Kit (Tiangen, Beijing, China) was used to obtain hepatic genomic DNA. RNA extraction was performed according to the TRIzol Reagent protocol (Invitrogen, Carlsbad, USA). The concentration of DNA and RNA was determined by measuring the absorbance at $260 \mathrm{~nm}$ using a NanoDrop 2000c spectrophotometer (Thermo Fisher Scientific Inc, Delaware, USA). Finally, DNA was stored at $-20{ }^{\circ} \mathrm{C}$ and prepared for bisulfite modification. RNA was diluted to a final concentration of $500 \mathrm{ng} / \mu \mathrm{L}$ and used to complete cDNA synthesis by Primer Script RT Reagent Kit (TaKaRa, Dalian, China). All cDNA samples were stored at $-20^{\circ} \mathrm{C}$.

\section{Real-time quantitative PCR}

The mRNA levels of IGF2 and DNMT1 in liver were quantified. The assay were carried out via the SYBR Premix Ex Taq kit (TaKaRa, Dalian, China) on the IQ5 (Bio-Rad, Hercules, USA). Reaction system of $20 \mu \mathrm{L}$ contained the following: $1 \mu \mathrm{L} c \mathrm{cDNA}, 1 \mu \mathrm{L}$ each primer $(10 \mathrm{pmol} / \mu \mathrm{L}), 10 \mu \mathrm{L}$ SYBR Premix Ex Taq and $7 \mu \mathrm{L}$ nuclease free water. Primers sequence were shown in Table 1. Protocols were set as follows: $95{ }^{\circ} \mathrm{C}$ for $5 \mathrm{~min}$; followed by 40 cycles of $95{ }^{\circ} \mathrm{C}$ for $10 \mathrm{~s}, 60{ }^{\circ} \mathrm{C}$ for $30 \mathrm{~s}$, and $72{ }^{\circ} \mathrm{C}$ for $30 \mathrm{~s}$; with a final extension at $72{ }^{\circ} \mathrm{C}$ for $5 \mathrm{~min}$. We ensured that data could be used for analysis when melting curve was specific and unimodal. Finally, the average cycle threshold $(\mathrm{Ct})$ values after normalizing to $\beta$-action were used for quantification by the $2^{-\Delta \Delta C t}$ method [17].

\section{Bisulfite conversion and sequencing}

The methylation of IGF2 gene promoter was analyzed by bisulfite sequencing. For six replicates in each group, equal quantity of DNA from 2 samples was mixed as a DNA pool. Hence, three DNA pools from each group were performed by sodium bisulfite treatment using the EZ DNA Methylation Kit (Zymo Research, USA). The primers for 
Table 1 Forwards (F) and reverse (R) primers of genes for RT-qPCR analysis

\begin{tabular}{llll}
\hline Genes & $\begin{array}{l}\text { Accession } \\
\text { number }\end{array}$ & Primer sequences, 5'to3' & $\begin{array}{l}\text { Product } \\
\text { size, bp }\end{array}$ \\
\hline B-actin & L08165 & F: ATTGTCCACCGCAAATGCTTC & 113 \\
& & R: AAATAAAGCCATGCCAATCTCGTC \\
IGF2 & NM001030342 & F: AGACCAGTGGGACGAAATAACA & 131 \\
& & R: CACGCTCTGACTTGACGGAC & \\
DNMT1 NM206952 & F: ACAGCCTCGCCGATACA & 248 \\
& & R: CTCTCCACCTGCTCCACCAC & \\
HAT1 NM204207 & F: AGAAGTTGACTGTGTGGAGGC & 152 \\
& & R: AGAATATGTGTGCAGCAGCATT & \\
\hline
\end{tabular}

bisulfite sequencing PCR (BSP) were as follows: forward TGG TTG TGT TGT AGA TTT TTT TTG T, reverse ACA CT AAA TTT CAC CTC CCA TTT T. They were designed by online Methprimer software (http://www. urogene.org/cgi-bin/methprimer/methprimer.cgi). Modified genomic DNA was served as the template for PCR amplification immediately and PCR products were gel purified using Gel Purification Kit (TaKaRa, Dalian, China). Then purified DNA were cloned into the pMD19-T vector (TaKaRa, Dalian, China) and used for transformation of competent Escherichia coli. Later, cells were plated on LB ager and identified by blue-white selection. Detailed methods above were under previous research [18]. Positive clones for each subject were randomly selected and grown overnight into LB broth and then LB broth were collected for sequencing (Sangon, Shanghai, China). The final sequence results were analyzed by online QUMA software (http://quma.cdb.riken.jp/).

\section{Chromatin looseness by DNase-qPCR assay}

Nuclei from the liver tissue were isolated using Nuclear Extraction Kit (Solarbio, Beijing, China). DNase I digestion and qPCR assays were carried out as described by the methods $[19,20]$. Briefly, nuclei were digested with DNase I (Thermo, Beijing, China). Then protein digestion was performed by proteinase K. Finally, DNA in the reaction mixture was purified using QIAquick PCR Purification Kit (Qiagen, Germany). Purified DNA was used for PCR. Reaction system was similar to the $\mathrm{qPCR}$ assay. The primer had following sequence: forward CAG GTG GTG CTG CGA TGA C, reverse CGG AGA TGG AGC CGA AGC. The cycle programs were performed as follows: an initial step at $95{ }^{\circ} \mathrm{C}$ for $15 \mathrm{~min}$; then 10 cycles of $94{ }^{\circ} \mathrm{C}$ for $15 \mathrm{~s}, 70{ }^{\circ} \mathrm{C}$ for $30 \mathrm{~s}$ and $72{ }^{\circ} \mathrm{C}$ for $45 \mathrm{~s}$; followed by 35 cycles of $94{ }^{\circ} \mathrm{C}$ for $15 \mathrm{~s}, 60{ }^{\circ} \mathrm{C}$ for $30 \mathrm{~s}$ and $72{ }^{\circ} \mathrm{C}$ for $45 \mathrm{~s}$. Data were analyzed as previously reported [20].

\section{Statistical analysis}

Experimental data were analyzed by one way ANOVA and regression analysis using SPSS 20.0 (SPSS Inc.,
Chicago, IL, USA). Correlation analysis were conducted by Pearson correlation. A probability value of $P<0.05$ was considered to be statistically significant and the notable differences between groups were identified by Duncan's multiple comparisons test. The methylation levels of each CpG site were tested by Fisher's exact test and the total methylation was tested by Mann-Whitney U-test according to the online QUMA software.

\section{Results}

\section{Performance of new-hatched broilers}

The fertilized hatchability of four groups are orderly 79.2, 79.3, 90.9 and $89.6 \%$ (data not shown). Based on the Chi-square test, 100 and $150 \mu \mathrm{g}$ folic acid improved the hatchability compared with the control group $(P<0.05)$. As shown in Table 2, BW, liver and bursa index of chickens in $150 \mu \mathrm{g}$ folic acid group were markedly higher than the other groups. However, folic acid had no effects on spleen and heart index.

\section{IGF2 expression}

Hepatic IGF2 expression of birth chicken was shown in Fig. 1. Results indicated that injecting $150 \mu \mathrm{g}$ folic acid on E11 up-regulated IGF2 expression $(P<0.05)$, but there were no significant differences between control and lower dose folic acid groups. No curve fitting methods was found by regression analysis using SPSS statistical software $(P>0.05)$.

\section{Methylation levels of IGF2 promoter region}

The methylation levels of IGF2 promoter were shown in Fig. 2. The methylation of -566 and -527 CpG sites were not affected by the folic acid. However methylation level of -587 CpG site decreased significantly in $150 \mu \mathrm{g}$ folic acid group when compared with the control. As for $-575 \mathrm{CpG}$ site, methylation level in $150 \mu \mathrm{g}$ folic acid group was lower than that in $50 \mu \mathrm{g}$ folic acid group. Total methylation level of IGF2 promoter were lower in 100 and $150 \mu \mathrm{g}$ folic

Table 2 Effects of folic acid injected at E11 on organ index and birth weight of broilers

\begin{tabular}{|c|c|c|c|c|c|c|}
\hline \multirow[t]{2}{*}{ Item } & \multicolumn{4}{|c|}{ Folic acid, $\mu \mathrm{g}$} & \multirow[t]{2}{*}{ SEM } & \multirow[t]{2}{*}{$P$-value } \\
\hline & 0 & 50 & 100 & 150 & & \\
\hline${ }^{1} \mathrm{BW}, \mathrm{g}$ & $43.00^{b c}$ & $42.25^{c}$ & $44.00^{b}$ & $45.67^{a}$ & 0.432 & 0.005 \\
\hline${ }^{2}$ Spleen index $10^{-2}$ & 0.036 & 0.029 & 0.033 & 0.045 & 0.002 & 0.065 \\
\hline Heart index, $10^{-2}$ & 0.603 & 0.485 & 0.633 & 0.693 & 0.030 & 0.054 \\
\hline Liver index, $10^{-2}$ & $1.63^{b}$ & $1.33^{b}$ & $1.58^{b}$ & $2.21^{\mathrm{a}}$ & 0.103 & 0.001 \\
\hline Bursa index, $10^{-2}$ & $0.082^{b}$ & $0.063^{c}$ & $0.073^{b c}$ & $0.100^{\mathrm{a}}$ & 0.005 & 0.004 \\
\hline
\end{tabular}




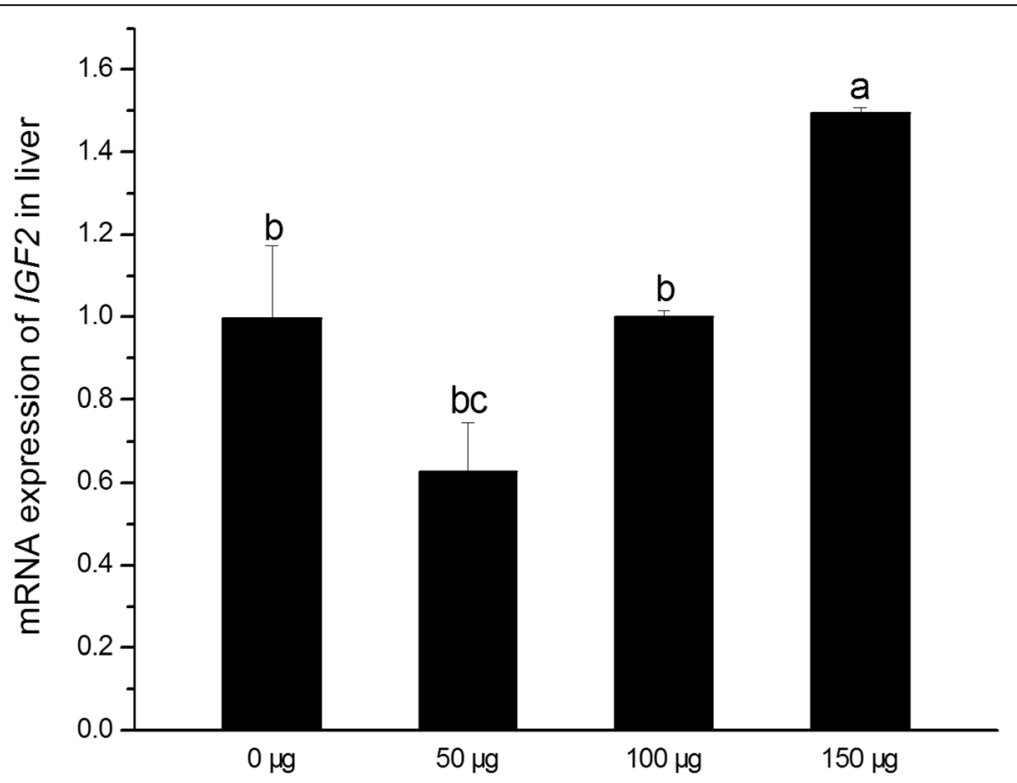

Fig. 1 Effects of in ovo folic acid injection on IGF2 mRNA expression in the liver of new-born chickens. Numerical values $(0,50,100,150 \mu \mathrm{g})$ in $X$-axis mean the amount of folic acid which was injected into eggs. Data were presented as means \pm SEM $(n=6)$. Bars with different letters are significantly different $(P<0.05)$. The $P$ values for linear and quadratic regression analysis were 0.324 and 0.225 , respectively

acid groups than the control and $50 \mu \mathrm{g}$ folic acid groups $(P<0.05)$. No curve fitting methods was found by regression analysis using SPSS statistical software (shown in Additional file 1) for total and single site methylation level $(P>0.05)$.

\section{Chromatin looseness of IGF2 promoter region}

As depicted in Fig. 3, the promoter region revealed higher chromatin looseness in $150 \mu \mathrm{g}$ folic acid group after DNase I digestion when compared with the other groups $(P<0.05)$, while 50 or $100 \mu \mathrm{g}$ folic acid didn't affect chromatin looseness of IGF2 promoter region.

\section{DNMT1 expression}

As shown in Fig. 4, DNMT1 expression was downregulated in 100 and $150 \mu \mathrm{g}$ folic acid groups $(P<0.05)$. Compared with control group, $50 \mu \mathrm{g}$ folic acid injection didn't affect DNMT1 expression of liver. No curve fitting methods was found by regression analysis using SPSS statistical software $(P>0.05)$.

\section{Transcription factor binding sites prediction}

In order to speculate the relationship between IGF2 mRNA expression and the methylation of 4 CpGs examined in the IGF2 promoter regions, the sequence including the $4 \mathrm{CpGs}$ was submitted into the online software (http://www.genomatix.de) to obtain the latent transcription factors bound at the $4 \mathrm{CpG}$ sites. Results predicted are shown in Fig. 5. In line with expectations, there were 7 potential transcription factors found in the predictive sequence, and introductions of these transcription factors were presented in Fig. 5b, c, d and e.

Correlations between hepatic IGF2 and BW and organ index As shown in Table 3, results indicated that BW of chickens and organ index was positively related to IGF2 expression level of the liver $(P<0.01)$. What's more, BW showed a significantly positive correlation with the organs index $(P<0.01)$.

\section{Discussion}

Mechanisms of epigenetic regulation contain DNA methylation, histone modification, chromatin remodeling in mammals, which modulate chromatin structure and contribute to regulation of molecular processes including transcription and repair [21]. The previous review has proposed that DNA methylation in the promoters or other regulatory regions might prevent stable binding of regulatory activator proteins to that sequence, thereby preventing gene expression [21]. Another mechanism is mediated by DNA-binding proteins which contain methylated DNA-binding domains [22]. The methylated $\mathrm{CpG}$ dinucleotide are recognized and bound by these methylated DNA-binding proteins, then the proteins in turn interact with or recruit other transcriptional silencing complexes which work to form a tight chromatin structure at the relevant gene [23]. It is a big challenge for researchers to understand epigenetic mechanisms of gene regulation absolutely in biological progress. 

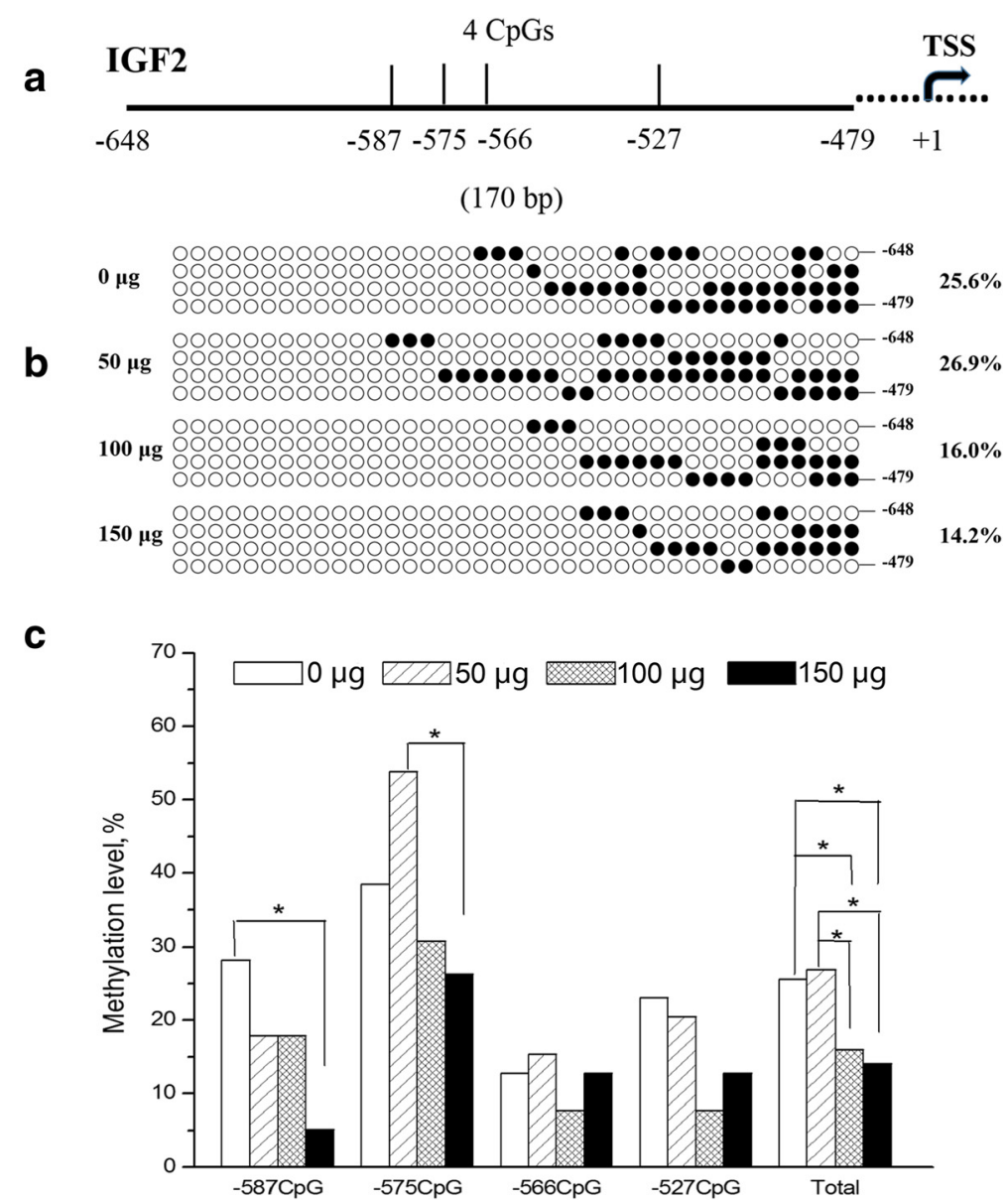

Fig. 2 Methylation analysis of the IGF2 promoter region in the liver. a Map of CpG dinucleotide in IGF2 promoter regions are presented by the ratable line. Numbers under the line are the positions relative to the transcription start site (TSS). $\mathbf{b}$ The methylation patterns of each CpG site were shown as maps of empty and full circles. Empty circles showed unmethylated CpGs and full circles methylated CpGs. Each vertical line is made up of four circles and represent one bacterial clone. $\mathbf{c}$ The total methylation and each CpG site methylation level of promoter region were calculated by analyzing the 39 clones in total. The asterisk $\left(^{*}\right)$ indicated statistically significant differences $(P<0.05)$. The $P$ values for linear and quadratic regression analysis were $>0.05$

Many studies suggested that IGF2 is indeed more influential than IGF1 for embryo and organ growth in the embryonic development of birds [24-26]. Our data showed that hepatic IGF2 expression was up-regulated by injecting $150 \mu \mathrm{g}$ folic acid on E11 during incubation period, while 50 and $100 \mu \mathrm{g}$ folic acid might be too less to reach the same effect. Meanwhile, BW, liver and bursa index of new-hatched chickens in $150 \mu \mathrm{g}$ folic acid group increased when compared with the control. Previous study reported that there were correlations between body weight of chick embryo and plasma IGFs level [27]. The liver, as a center of metabolism, was considered to be the major source of blood IGF2 circulation which exerted endocrine functions [12]. It's well apparent that hepatic IGF2 expression is important for the growth and development of broilers embryos. Previous study indicated that body and liver weight were related to hepatic IGFs gene expression in ducks [24].
In order to further demonstrate whether the methylation of IGF2 promoter was served as the regulatory factor for gene expression, we detected the methylation status of IGF2 gene promoter region. What is more intriguing was that methylation level of IGF2 promoter region was lower in $150 \mu \mathrm{g}$ folic acid group, which was consistent with the result of IGF2 overexpression. DNA methylation affected gene expression by disturbing the binding of specific transcription factors [28]. Whereupon it could be legitimately extrapolated that hypomethylation of IGF2 promoter might activate gene transcription in virtue of attracting the co-localized transcription factors, subsequently up-regulating IGF2 expression. Just as the prediction, 7 various potential transcription factors were located abundantly at four CpGs in the promoter region.

Although folic acid's role in one carbon metabolism is related to increasing DNA methylation, from other 


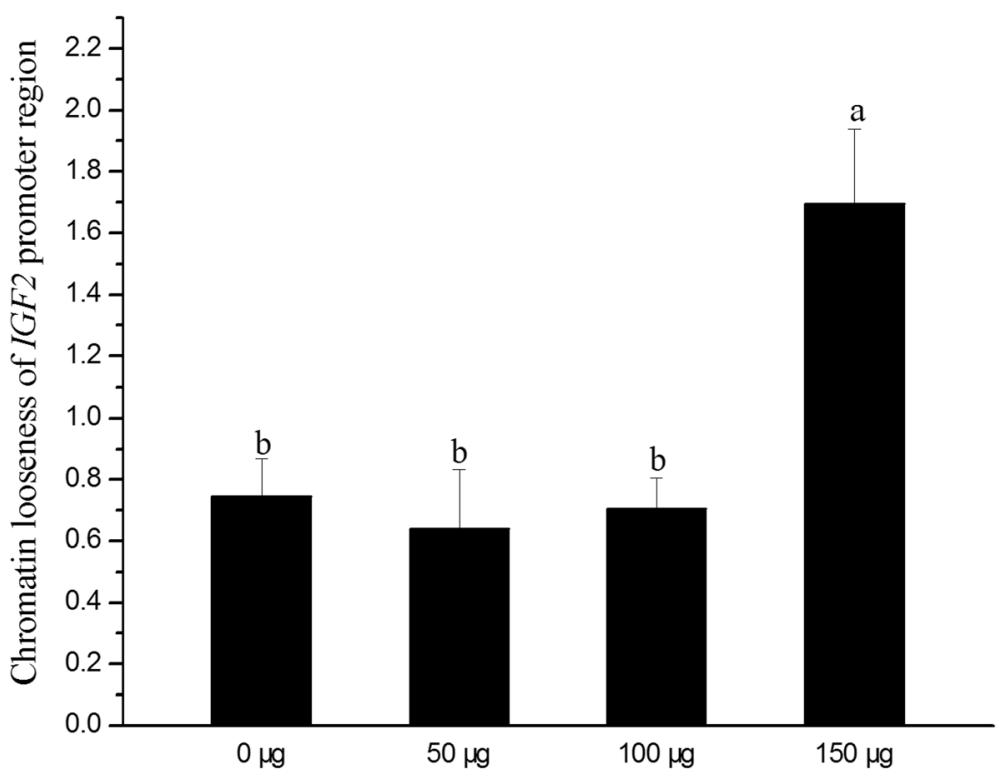

Fig. 3 Effects of in ovo folic acid injection on chromatin looseness of IGF2 promoter region in the liver. Numerical values $(0,50,100,150 \mu \mathrm{g})$ in $X$-axis mean the amount of folic acid which was injected into eggs. Bars with different letters are significantly different $(P<0.05)$

aspects it is not difficult to understand the phenomenon in the study that folic acid decreased total methylation level of gene promoter region. Firstly, some other nutrients are involved in one carbon flux to ensure homocysteine remethylation, $\mathrm{S}$ adenosyl methionine (SAM) formation and DNA methylation such as choline, betaine and other B vitamins [11]. Therefore methylation status is not only depended on the folic acid. Secondly, methionine is the substrate for SAM, which is the methyl donor in transmethylation reaction of DNA methylation [29]. The conversion of homocysteine to methionine benefits from the methyl group donated by 5-Methyl-THF, which finally turns into tetrahydrofolate (THF) in this bidirectional reaction.

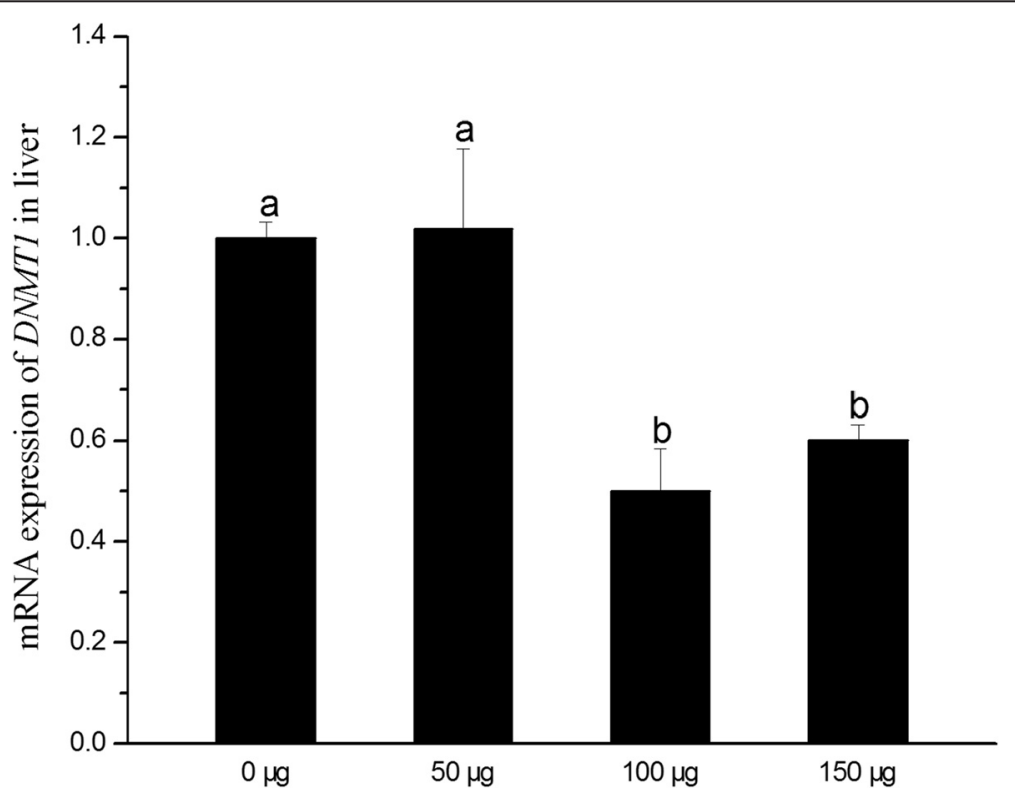

Fig. 4 Effects of in ovo folic acid injection on hepatic DNMT1 expression in the new-born chickens. Numerical values (0,50, 100, 150 $\mu \mathrm{g})$ in X-axis mean the amount of folic acid which was injected into eggs. Data were presented as means \pm SEM $(n=6)$. Bars with different letters are significantly different $(P<0.05)$. The $P$ values for linear and quadratic regression analysis were 0.175 and 0.558 , respectively 


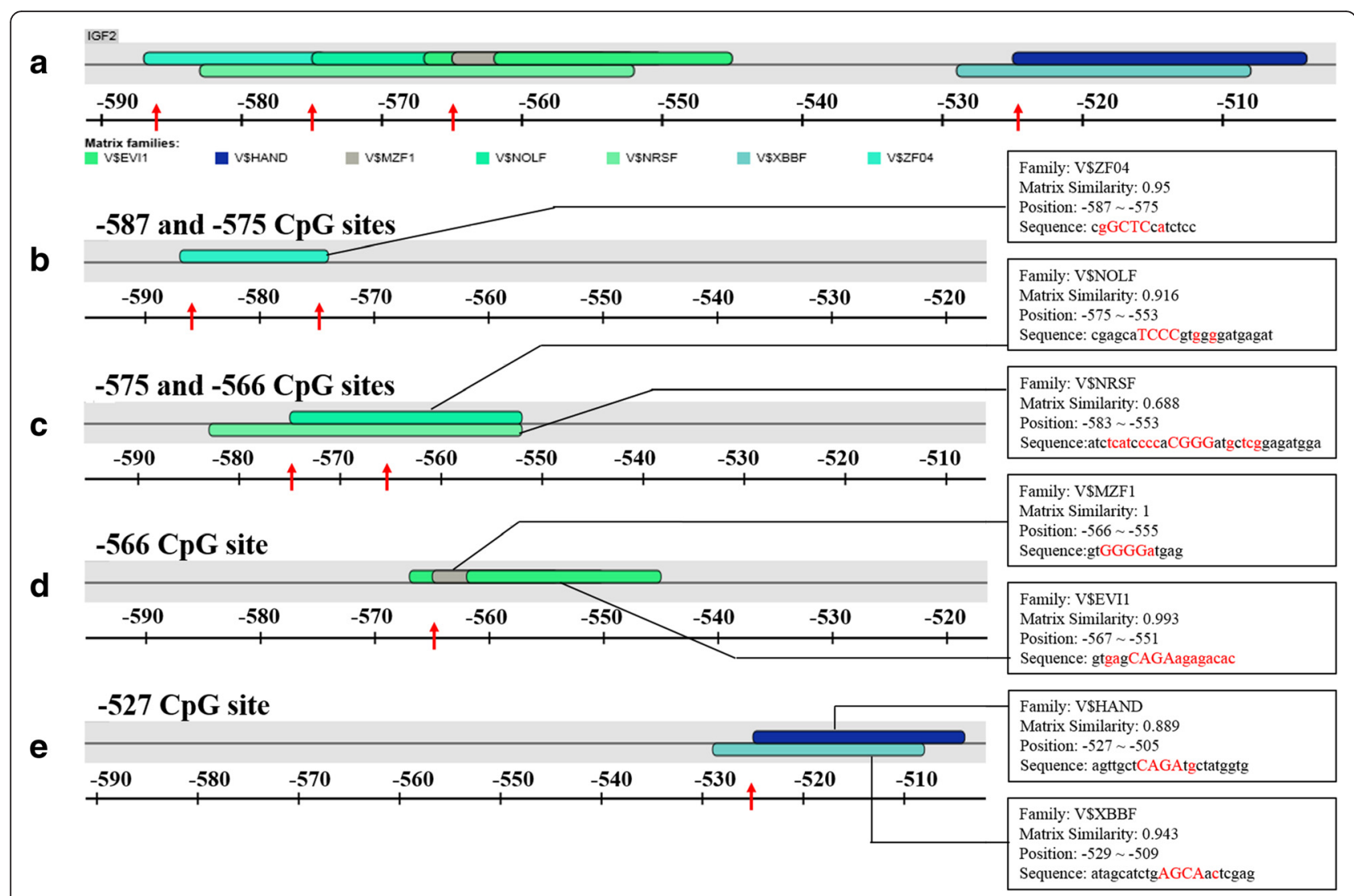

Fig. 5 Transcription factor binding site (TFBS) prediction in the IGF2 promoter regions. a Total predicted transcription factors involving the four CpG sites in the promoter of IGF2 gene. The red arrows represent the distribution of the CpG loci. $\mathbf{b}$ The partial predicted transcription factors related to -587 and $-575 \mathrm{CpG}$ sites and the same as below. c, d and $\mathbf{e}$ are correlated with -575 and $-566 \mathrm{CpG}$ sites, $-566 \mathrm{CpG}$ site and $-527 \mathrm{CpG}$ site respectively. Contents in the boxes describe detailed information of transcription factors which might combine the region containing the $\mathrm{CpG}$ sites

However folic acid is originally first reduced to dihydrofolate (DHF) and then to THF by DHF reductase, thus the level of THF produced from folic acid might suppress homocysteine remethylation reaction. Besides, homocysteine remethylation is the only known reaction involving 5-methyl THF whose synthesis is in a unidirectional reaction catalyzed by methylenetetrahydrofolate reductase (MTHFR). The production of 5-methyl THF by MTHFR is an important and

Table 3 Correlation between hepatic IGF2 expression and birth weight and organ index

\begin{tabular}{lllllll}
\hline Item & IGF2 & BW & Spleen & Heart & Liver & Bursa \\
\hline IGF2 & 1 & & & & & \\
BW & $0.945^{\mathrm{a}}$ & 1 & & & & \\
Spleen & $0.898^{\mathrm{a}}$ & $0.872^{\mathrm{a}}$ & 1 & & & \\
Heart & $0.932^{\mathrm{a}}$ & $0.894^{\mathrm{a}}$ & $/$ & 1 & & \\
Liver & $0.954^{\mathrm{a}}$ & $0.928^{\mathrm{a}}$ & $/$ & $/$ & 1 & \\
Bursa & $0.942^{\mathrm{a}}$ & $0.856^{\mathrm{a}}$ & $/$ & $/$ & $/$ & 1
\end{tabular}

ashows that there is a significant correlation between two indices at the 0.01 level (two- tailed) regulatory step in one carbon metabolism cycle. But SAM is a potent inhibitor of MTHFR, and folic acid may disturb regulation of one carbon metabolism by interfering with the inhibitory effect of SAM on MTHFR activity [30].

The mechanisms associated with effects of folic acid on DNA methylation are complex and not fully understood. The previous study found that using of folic acid before and during pregnancy was connected with lower methylation levels at DNA sequences regulating IGF2 expression [31], which suggested that folic acid might lower methylation level in site-specific DNA of the gene. Another research indicated that increased serum folate among smokers was associated with decreased methylation of five detected genes [32]. What's more, the lowest methylation level at the second site of the PPARY promoter was examined in cells exposed to $4 \mathrm{mg} / \mathrm{L}$ of folate [33]. These researches all conformed to the effects of folic acid on DNA hypomethylation of IGF2 promoter region in our study.

One possible mechanism that caused changes in methylation level as well as chromatin structure was 
enzymes activity. DNMT1 plays a vital part in the maintenance of methylation especially in tissues of adults after fertilization [34], and unnatural expression of IGF2 was found in DNMT1 knock-out mice [35]. In present study, we detected lower expression of hepatic DNMT1 in 100 and $150 \mu \mathrm{g}$ folic acid groups which were consistent with the results of DNA hypomethylation. Hypomethylation of a conserved single CpG in DNMT1 had a positive correlation with gene expression of DNMT1 [36]. The previous study showed that choline deficiency induced the hypomethylation of regulatory CpG in the $D N M T 1$ gene, leading to overexpression of DNMT1 and the final higher methylation level in global and genespecific DNA [18]. Thus, taken together, our data obviously pointed to the relationship that in ovo folic acid injection on E11 caused decline of DNMT1 expression followed by hypomethylation in IGF2 promoter regions leading to an acceleration of IGF2 expression. Likely, the former may be due to the hypermethylation of the CpG in DNMT1 regulatory region induced by folic acid.

The phenomenon was doubtful that low methylation level of IGF2 promoter and DNMT1 down-regulation in $100 \mu \mathrm{g}$ folic acid group didn't result in IGF2 overexpression. We examined the chromatin structure of $I G F 2$ promoter in order to illuminate the doubt. Our data showed that another contributing factor for the detected hepatic IGF2 overexpression was chromatin looseness of IGF2 promoter. Because $150 \mu \mathrm{g}$ folic acid injection improved chromatin looseness in the study, but this result was not found in $100 \mu \mathrm{g}$ folic acid group. Gene expression could be induced by local chromatin structures which regulate transcription factor binding activities [37]. Chromatin is a DNA-protein complex, and protein components are core histones. Hence, it might be probable that chromatin of IGF2 promoter region was changed into loose status to facilitate gene transcription. So the doubt mentioned above could be clarified. The possible explanation is that IGF2 transcription might depend on both methylation and chromatin structure of IGF2 promoter regions.

In the study, lower level of folic acid didn't affect hepatic IGF2 expression. It was likely that the dose of 50 and $100 \mu \mathrm{g}$ folic acid might be not enough to change the methylation and chromatin structure at the same time. Automatically embryonic growth and organ development of new-hatched chicken couldn't gain corresponding improvement. Even so, the internal causal relationship between methylation status and chromatin structure of IGF2 promoter regions is unclear.

\section{Conclusion}

In conclusion, the present study has demonstrated that the effects of in ovo folic acid injection on hepatic IGF2 expression and embryo growth of chickens. Our results likely have general implications that embryo growth and organ development of chicken have a positive correlation with hepatic IGF2 expression. $150 \mu \mathrm{g}$ folic acid injected on E11 might up-regulate IGF2 expression by decreasing methylation and improving chromatin accessibility of gene promoter, which offers new insights into the field of nutriepigenetics. But internal relationship between DNA methylation and chromatin structure affected by folic acid is expected for further research.

\section{Additional file}

Additional file 1: The summary of regression analysis for methylation data. (DOC $42 \mathrm{~kb}$ )

\section{Acknowledgments}

The work was supported by the Natural Science Foundation of China (No. 31272464), the Program for New Century Excellent Talents (NCET-12-0476), and the Program for Shaanxi Science \& Technology (2014 K01-18-02, 2015NY149, 2015KTCQ02-19).

\section{Authors' contributions}

YLL, LHZ and XJY designed the research; YLL, LHZ, JS and SZL performed the research and analysed the data; YLL wrote the manuscript; SJ, JHY and XJY have taken part in the revision of the manuscript. All authors read and approved the final version of the manuscript.

\section{Competing interests}

The authors declare that they have no competing interests.

\section{Author details}

${ }^{1}$ College of Animal Science and Technology, Northwest A\&F University, Yangling 712100, China. ' ${ }^{2}$ chool of Mathematics and Computer Science, ShanXi Normal University, Linfen 041000, China.

Received: 23 January 2016 Accepted: 28 June 2016

Published online: 22 July 2016

\section{References}

1. Yokomine T, Shirohzu H, Purbowasito W, Toyoda A, Iwama H, Ikeo K, et al. Structural and functional analysis of a $0.5-\mathrm{Mb}$ chicken region orthologous to the imprinted mammalian Ascl2/Mash2-Igf2-H19 region. Genome Res. 2005;15(1):154-65

2. Amills $M$, Jimenez $N$, Villalba D, Tor M, Molina E, Cubilo D, et al. Identification of three single nucleotide polymorphisms in the chicken insulin-like growth factor 1 and 2 genes and their associations with growth and feeding traits. Poult Sci. 2003;82(10):1485-93.

3. Wang H-B, Li H, Wang Q-G, Zhang $X-Y$, Wang S-Z, Wang $Y-X$, et al. Profiling of chicken adipose tissue gene expression by genome array. BMC Genomics. 2007:8(1):193.

4. McMurtry JP. Nutritional and developmental roles of insulin-like growth factors in poultry. J Nutr. 1998;128(2):302s-5

5. Beccavin C, Chevalier B, Cogburn LA, Simon J, Duclos MJ. Insulin-like growth factors and body growth in chickens divergently selected for high or low growth rate. J Endocrinol. 2001;168(2):297-306.

6. Hillier LW, Miller W, Birney E, Warren W, Hardison RC, Ponting CP, et al. Sequence and comparative analysis of the chicken genome provide unique perspectives on vertebrate evolution. Nature. 2004;432(7018):695-716.

7. Bakyaraj S, Bhanja SK, Majumdar S, Dash B. Modulation of post-hatch growth and immunity through in ovo supplemented nutrients in broiler chickens. J Sci Food Agric. 2012;92(2):313-20.

8. Leung KY, De Castro SC, Cabreiro F, Gustavsson P, Copp AJ, Greene ND. Folate metabolite profiling of different cell types and embryos suggests variation in folate one-carbon metabolism, including developmental changes in human embryonic brain. Mol Cell Biochem. 2013;378(1-2):229-36. 
9. Fazzari MJ, Greally JM. Introduction to epigenomics and epigenome-wide analysis. Statistical methods in molecular biology. Bronx: Humana Press; 2010. p. 243-65

10. Chen P, Li C, Li X, Li J, Chu R, Wang H. Higher dietary folate intake reduces the breast cancer risk: a systematic review and meta-analysis. Brit J Cancer. 2014;110(9):2327-38

11. Anderson OS, Sant KE, Dolinoy DC. Nutrition and epigenetics: an interplay of dietary methyl donors, one-carbon metabolism and DNA methylation. J Nutr Biochem. 2012;23(8):853-9.

12. McMurtry JP, Francis GL, Upton Z. Insulin-like growth factors in poultry. Domest Anim Endocrinol. 1997;14(4):199-229.

13. DeChiara TM, Robertson EJ, Efstratiadis A. Parental imprinting of the mouse insulin-like growth factor II gene. Cell. 1991;64(4):849-59.

14. DeChiara TM, Efstratiadis A, Robertsen EJ. A growth-deficiency phenotype in heterozygous mice carrying an insulin-like growth factor II gene disrupted by targeting. Nature. 1990;345:78-80.

15. Ohta Y, Tsushima N, Koide K, Kidd M, Ishibashi T. Effect of amino acid injection in broiler breeder eggs on embryonic growth and hatchability of chicks. Poult Sci. 1999;78(11):1493-8.

16. Li S, Zhi L, Liu Y, Shen J, Liu L, Yao J, et al. Effect of in ovo feeding of folic acid on the folate metabolism, immune function and epigenetic modification of immune effector molecules of broiler. Brit J Nutr. 2016;115(03):411-21.

17. Livak KJ, Schmittgen TD. Analysis of relative gene expression data using real-time quantitative $P C R$ and the $2<$ sup $>-\Delta \Delta C T</$ sup $>$ method. Methods. 2001;25(4):402-8.

18. Kovacheva VP, Mellott TJ, Davison JM, Wagner N, Lopez-Coviella I, Schnitzler AC, et al. Gestational choline deficiency causes global and lgf2 gene DNA hypermethylation by up-regulation of dnmt1 expression. J Biol Chem. 2007; 282(43):31777-88.

19. Ling G, Waxman DJ. DNase I digestion of isolated nulcei for genome-wide mapping of DNase hypersensitivity sites in chromatin. Gene regulation. Boston: Humana Press; 2013. p. 21-33.

20. Shu H, Gruissem W, Hennig L. Measuring Arabidopsis chromatin accessibility using DNase I-polymerase chain reaction and DNase I-chip assays. Plant Physiol. 2013;162(4):1794-801.

21. Crider KS, Yang TP, Berry RJ, Bailey LB. Folate and DNA methylation: a review of molecular mechanisms and the evidence for folate's role. Adv Nutr. 2012; 3(1):21-38.

22. Dhasarathy A, Wade PA. The MBD protein family-reading an epigenetic mark? Mutat Res. 2008;647(1-2):39-43.

23. Miranda TB, Jones PA. DNA methylation: the nuts and bolts of repression. J Cell Physiol. 2007;213(2):384-90.

24. Jianmin Z, Jingting S, Yanju S, Yan H, Chi S, Wenqi Z. Expression of insulinlike Growth factor system genes in liver tissue during embryonic and early post-hatch development in duck (Anas platyrhynchos Domestica). Anim Biotechnol. 2014;25(2):73-84

25. Richards MP, Poch SM, McMurtry JP. Expression of insulin-like growth factor system genes in liver and brain tissue during embryonic and post-hatch development of the turkey. Comp Biochem Phys A. 2005;141(1):76-86

26. McMurtry JP, Rosebrough RW, Brocht DM, Francis GL, Upton Z, Phelps P. Assessment of developmental changes in chicken and turkey insulin-like growth factor-II by homologous radioimmunoassay. J Endocrinol. 1998;157(3):463-73.

27. Lu JW, McMurtry JP, Coon CN. Developmental changes of plasma insulin, glucagon, insulin-like growth factors, thyroid hormones, and glucose concentrations in chick embryos and hatched chicks. Poult Sci. 2007:86(4):673-83.

28. Robertson KD. DNA methylation and human disease. Nat Rev Genet. 2005; 6(8):597-610.

29. Stover PJ. One-carbon metabolism-genome interactions in folate-associated pathologies. J Nutr. 2009;139(12):2402-5.

30. Smith DE, Hornstra JM, Kok RM, Blom HJ, Smulders YM. Folic acid supplementation does not reduce intracellular homocysteine, and may disturb intracellular one-carbon metabolism. Clin Chem Lab Med. 2013;51(8):1643-50.

31. Hoyo C, Murtha AP, Schildkraut JM, Jirtle R, Demark-Wahnefried W, Forman MR, et al. Methylation variation at IGF2 differentially methylated regions and maternal folic acid use before and during pregnancy. Epigenetics. 2011;6(7):928-36.

32. Stidley CA, Picchi MA, Leng S, Willink $R$, Crowell RE, Flores KG, et al. Multivitamins, folate, and green vegetables protect against gene promoter methylation in the aerodigestive tract of smokers. Cancer Res. 2010;70(2):568-74.

33. Yu X, Liu R, Zhao G, Zheng M, Chen J, Wen J. Folate supplementation modifies CCAAT/enhancer-binding protein alpha methylation to mediate differentiation of preadipocytes in chickens. Poult Sci. 2014;93(10):2596-603.
34. Subramaniam D, Thombre R, Dhar A, Anant S. DNA methyltransferases: a novel target for prevention and therapy. Front Oncol. 2014:4:80.

35. Li E, Beard C, Jaenisch R. Role for DNA methylation in genomic imprinting Nature. 1993:366(6453):362-5.

36. Slack A, Cervoni N, Pinard M, Szyf M. DNA methyltransferase is a downstream effector of cellular transformation triggered by simian virus 40 large $T$ antigen. J Biol Chem. 1999;274(15):10105-12.

37. Chen J, Ivashkiv LB. IFN-gamma abrogates endotoxin tolerance by facilitating Toll-like receptor-induced chromatin remodeling. Proc Natl Acad Sci U S A. 2010;107(45):19438-43

\section{Submit your next manuscript to BioMed Central and we will help you at every step:}

- We accept pre-submission inquiries

- Our selector tool helps you to find the most relevant journal

- We provide round the clock customer support

- Convenient online submission

- Thorough peer review

- Inclusion in PubMed and all major indexing services

- Maximum visibility for your research

Submit your manuscript at www.biomedcentral.com/submit
Biomed Central 